\title{
医薬品の評価における体内分布試験の意義
}

\section{Meaning of Pharmacokinetic Distribution Study for Drug Evaluation}

\author{
粟津 荘司 \\ 東京薬科大学第 2 薬剤学教室
}

医薬品の評価における体内分布試験の意義は, 薬物動態試験ガイドラインの解説1)に述べられている ことに尽きると考えられる. すなわち「医薬品を投与して吸収, 分布, 代謝, 排泄について十分な検討 を加えることは, その医薬品の効果および持続時間ならびに作用機序等の予測に必要であるばかりでな く, 生体内の分布, 貯留時間, 濃度等を知ることにより副作用の発現の推定のために多大な情報を与え るものである.」ということになる.

これらの薬の体内動態を支配する四つの過程の内, 吸収と排泄は身体全体における薬の量と存在時間 の長さを, また代謝は薬の質的変化を規定するものである.これらが薬の効果と安全性に関する尺度と なることは容易に理解できることである．また分布は薬の臓器もしくは組織における量と存在時間を規 定するものといえる. 薬の作用(薬効と毒性)が臓器もしくは組織において発揮されると考えるならば, このデータはより直接的に薬の効果と安全性に関する物質的根拠を与えるものとなる. 薬効発現部位に 薬が薬効を発揮するに足る濃度で, 十分な時間が存在するという分布データは薬効発現を保証するもの になる. 毒性試験についても同様なことがいえる. 薬が長い時間高濃度である葴器もしくは組織に存在 することは，そこでの毒性発現の機会が高まる可能性を暗示する. 実際, 薬の分布が毒性もしくは有害 作用と発現に相関のあることは多くの例で知られている. 勿論, 薬の毒性は親化合物によるとは限らな い. 代謝物や代謝中間体が毒性の原因となることもあるし，それらが代謝部位とは異なる場所で毒性を 発揮する場合もある.したがってこれらを含めた分布データ（もしも可能ならば）が望ましいこととな る.いずれにせよ，これらの物質が長時間分布していることになれば，毒性発現の機会が増すことにな る.このようなことは実際には希であるにせよ,このことがある薬もしくは被験物質に蓄積性があると いうときにマイナス感を与える原因である.

しかしながら蓄積性という言葉の定義には曖昧な点がある. ファーマコキネティクスでよく知られて いるように, 薬を反復投与すれば次式で得られる係数に相当する倍数だけ血中濃度は上昇することにな る.この係数は蓄積係数 (accumulation factor) と呼ばれるから, この限りでは蓄積は薬の反復投与に よりもたらされる当然の帰結であり, あらゆる薬や物質には蓄積性があるということになり, 蓄積性の 有無を議論することは無意味になってしまう. 問題となるのはこの式では予測できない程度に濃度が上 昇することであろうが，このことを的確に表す言葉がないのが現状である.

$$
\begin{aligned}
& \text { 蓄積係数 }=1 /(1-\exp (-\mathrm{k} \cdot \tau)) \\
& \text { ここで } \mathrm{k} \text { は消失速度定数, } \tau \text { は投与間隔とする. }
\end{aligned}
$$

また生理学的薬物速度論では薬の組織中濃度と血中濃度との比は一定とされており，この比は組織一 血液間の分配係数 $(\mathrm{Kp})$ と呼ばれる. 反復投与により血中濃度が蓄積係数よりも上昇する場合, さら には蔵器中濃度が上昇して $\mathrm{Kp}$ も時間の経過に従い増大する場合には，その蓄積性については注意する 
ことが必要となろう. すなわち単回投与により得られる $\mathrm{k}$ と $\mathrm{Kp}$ より蓄積性を求め, これと反復投与時 の血中および組織中濃度を比較することにより, 問題となる（もしくは問題となるかも知れない）蓄積 性の有無を議論することができる. しかしながら, 薬物動態誌を見る限りでは, このような解析を実際 の被験物質について行っている例は少ない2). 実際には, 単回投与時と反復投与時の血中濃度および組 織中濃度を比較して, 単回投与時に比較して何倍になったという程度の考察をしているに過ぎない. 最 終投与後に, 少々の消失の遅れがあってもそれが, やがて消失してし屯うならば問題とはならないと考 えている場合もあるだろうし，別途に毒性試験の結果と対比していることも考えられる. また，分布デ 一タをとるときには放射能測定によることが多く, 分離定量はなされていないので, あまり詳細な解析 は無意味とされているのであろう.しかしながらたとえ放射能のみの測定であっても, 単回投与データ からの予測值と反復投与データを比較することにより, 蓄積性に関する代謝物の寄与もある程度推定で きるのだから, 蓄積計数などを求めておきたいものである. 一つの実験により, 代謝に関する情報も得 られる点で, 実施に難点はあるが放射性同位元素による分布データの収集にはそれなりの利点もあると 考えられる.

なお分布の測定には放射性同位元素標識体（以下，標識体と略）は必ずしも必要としないが, 全身才 ートラジオグラムの測定には標識体が使用される. ラジオグラムを定量化するラジオルミノグラフィを TLC とともに用いれば，代謝物の分離定量を含んだ分布測定がより簡便に行えるようになるであろう.

以上のように反復投与により分布を測定することは, 被験物質の体内動態を知り, 毒性試験の補強に なると考えられるが，欧米では必ずしもこの反復投与による分布測定の必要性が認識されていない. 彼 らの論点は，1）単回投与により被験物質の分布は分かる，2）毒性試験の方法が進歩したので, 分布 データにより補強される必要はない，3）蓄積性と毒性とには必ずしも相関がない，4）たとえ蓄積性 があっても毒性がなければよい, などである. 毒性が検出された物質の研究は, 多くの場合その時点で 中止され，そのデータも公表されることが少ないので，以上のように断言できるかの疑問がある．いず れにせよ，この点に関しては昨年の ICH において一定の結論を得たことであるが, 国内手続きが進行 中であるので, このことについては別の機会に譲りたい.

文献

1) 医薬品臨床試験ガイドライン解説, 薬事日報社, p. 83 (1991).

2）溝口顕爾氏より示唆をいただいた. 